\title{
Analisis Pelaksanaan Program Keselamatan dan Kesehatan Kerja Dalam Upaya Meminimalkan Kecelakaan Kerja pada Pegawai PT. Kereta Api Indonesia (Persero)
}

\author{
Oleh ; \\ Heri Nugraha ${ }^{1)}$, Linda Yulia ${ }^{2)}$ \\ Institut Manajemen Koperasi Indonesia \\ herinugraha@ikopin.ac.id
}

\begin{abstract}
ABSTRAK
Pelaksanaan keselamatan dan kesehatan kerja yang dilakukan oleh seluruh pegawai haruslah berorientasi meminimalkan kecelakaan kerja. Penelitian ini bertujuan untuk mendeskripsikan pelaksanaan keselamatan dan kesehatan kerja dalam upaya meminimalkan kecelakaan kerja di PT. Kereta Api Indonesia. Teknik pengumpulan data yang digunakan dalam penelitian ini yaitu melakukan studi lapangan dengan pengamatan langsung, wawancara, dan dokumentasi. Analisis data yang digunakan dalam penelitian ini adalah analisis interaktif yang diawali dengan reduksi data, penyajian data dan penarikan kesimpulan untuk memperoleh gambaran mengenai fakta yang terjadi di lapangan. Hasil penelitian diperoleh bahwa, pelaksanaan program keselamatan dan kesehatan kerja pada PT. Kereta Api Indonesia tidak dilakukan secara maksimal karena terdapat kekurangan pada fasilitas dan minimnya jumlah peserta yang mengikuti pelatihan.
\end{abstract}

Kata Kunci: keselamatan dan kesehatan kerja, kecelakaan kerja

\section{ABSTRACT}

The implementation of occupational safety and health carried out by all employees must be oriented to completion of work. This study was designed to describe work safety and work safety at PT. Indonesian Railways. Data collection techniques used in this research are conducting field studies by direct monitoring, interviews, and documentation. Analysis of the data used in this study is an interactive analysis that begins with data reduction, data presentation and conclusion conclusions obtained about the facts that occur in the field. Research results Obtained from that, the implementation of occupational safety and health programs at PT. Indonesian Railways was not carried out due to lack of facilities and the minimal number of participants participating in the training.

Keywords: occupational safety and health, work accident

\section{PENDAHULUAN}

\section{Latar Belakang}

Perkembangan teknologi yang semakin pesat setiap tahunnya, secara tidak langsung mendorong setiap perusahaan untuk terus berkembang menggunakan berbagai teknologi baru. Kontribusi pekerja sebagai sumber daya manusia pada suatu perusahaan tidak dapat dipungkiri memiliki kendala yang dapat menyebabkan kecelakaan kerja.

Menurut International Labour Organization terbaru, lebih dari 1,8 juta kematian terjadi di Asia-
Pasifik. Di tingkat Asia sebesar dua pertiga dari keseluruhan global lebih dari 2,78 juta orang meninggal setiap tahun akibat kecelakaan atau penyakit akibat kerja. Selain itu, ada sekitar 374 juta kerusakan dan penyakit akibat kerja yang tidak fatal.

Sedangkan berdasarkan data BPJS Ketenagakerjaan, terdapat peningkatan jumlah kasus kecelakaan kerja Pada tahun 2015 terjadi kecelakaan kerja sebanyak 110.285 kasus, tahun 2016 terjadi 105.182 kasus, dan pada tahun 2017 sebanyak 123.000 kasus terjadi. 
Sumber daya manusia merupakan salah satu aset penting yang dimiliki perusahaan untuk menjalankan aktivitas organisasi. Perusahaan yang maju dan besar menjadikan pegawai sebagai aset yang perlu dillindungi, sesuai dengan UndangUndang Nomor 1 Tahun 1970 Pasal 1 tentang keselamatan kerja “...bahwa setiap tenaga kerja berhak mendapat perlindungan atas keselamatannya dalam melakukan pekerjaan untuk kesejahteraan hidup dan meningkatkan produksi serta produktivitas Nasional."

PT. Kereta Api Indonesia (Persero) merupakan salah satu badan usaha milik negara yang menyelenggarakan jasa angkutan transportasi darat, meliputi angkutan penumpang dan barang. Perusahaan memiliki sumber daya manusia yang berjumlah 300.000 pada tahun 2016 yang tersebar diseluruh daerah operasional Indonesia.
Kereta api menjadi salah satu moda transportasi yang diminati sebagian besar masyarakat Indonesia. Demi kenyamanan masyarakat sebagai konsumen, maka sarana dan prasarana berperan penting dalam perawatan kereta api. Perawatan sarana kereta api terdiri dari rangkaian dan lokomotif yang dilakukan di Depo Lokomotif.

Pegawai Depo Lokomotif bekerja dalam 3 shift dan berhadapan langsung dengan mesin diesel, sehingga pentingnya menerapan prosedur keselamatan dan kesehatan kerja untuk meminimalisir terjadinya kecelakaan kerja.

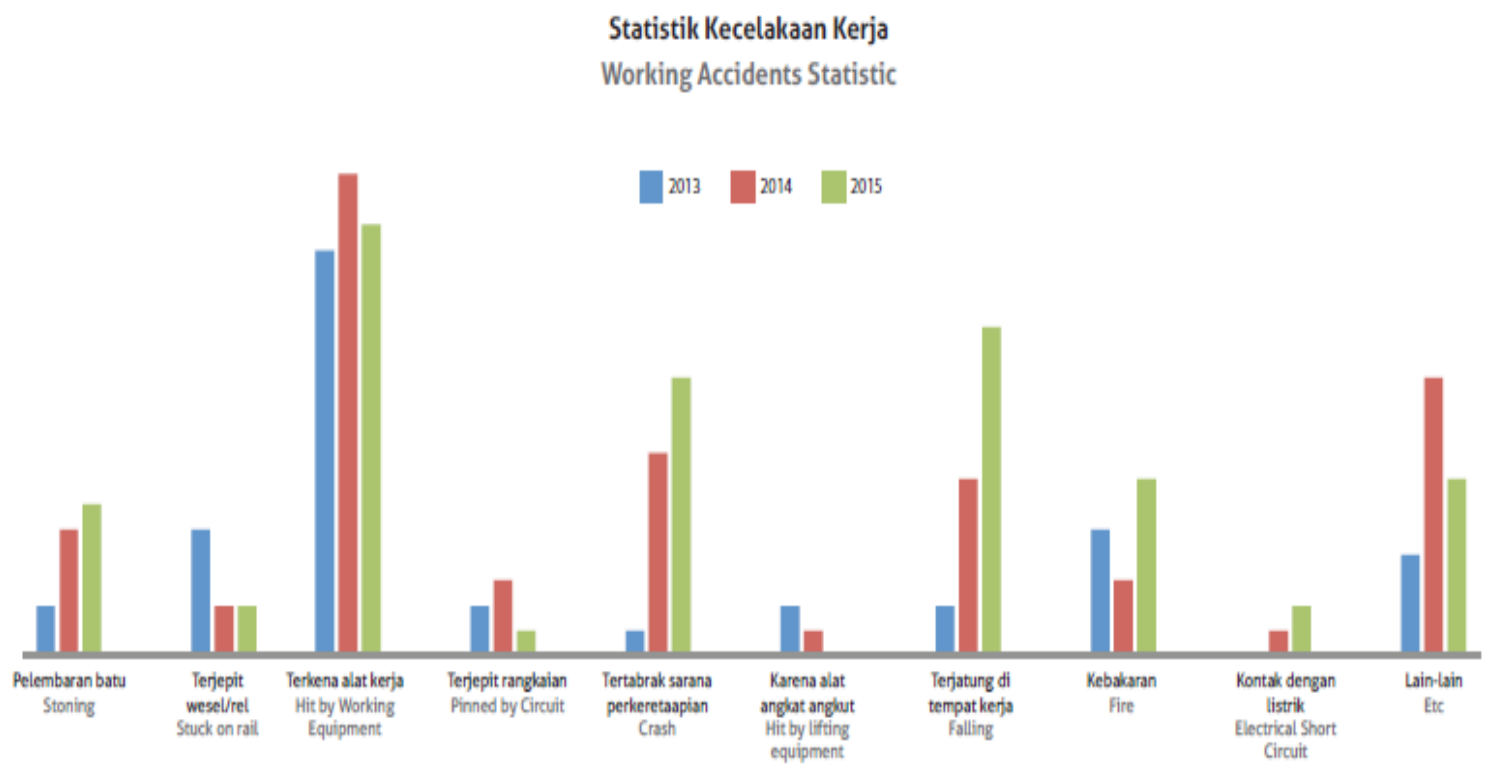

Gambar 1. Statistik Kecelakaan Kerja Tahun 2013-2015

Berdasarkan gambar 1. kecelakaan kerja pada tahun 2015 meningkat menjadi 66 kejadian dibandingkan tahun 2014 dengan total 60 kejadian. Selama tahun 2013-2015 kecelakaan kerja terbanyak disebabkan terkena alat kerja seperti mesin las, mesin gerinda, mesin press dan sebagainya. Pada tahun 2015, kasus pelemparan batu yang mengenai masinis/asisten masinis meningkat menjadi 6 kejadian. Kasus lain, peningkatan kecelakaan kerja akibat tertabrak sarana perkeretaapian dan terjatuh ditempat kerja. 


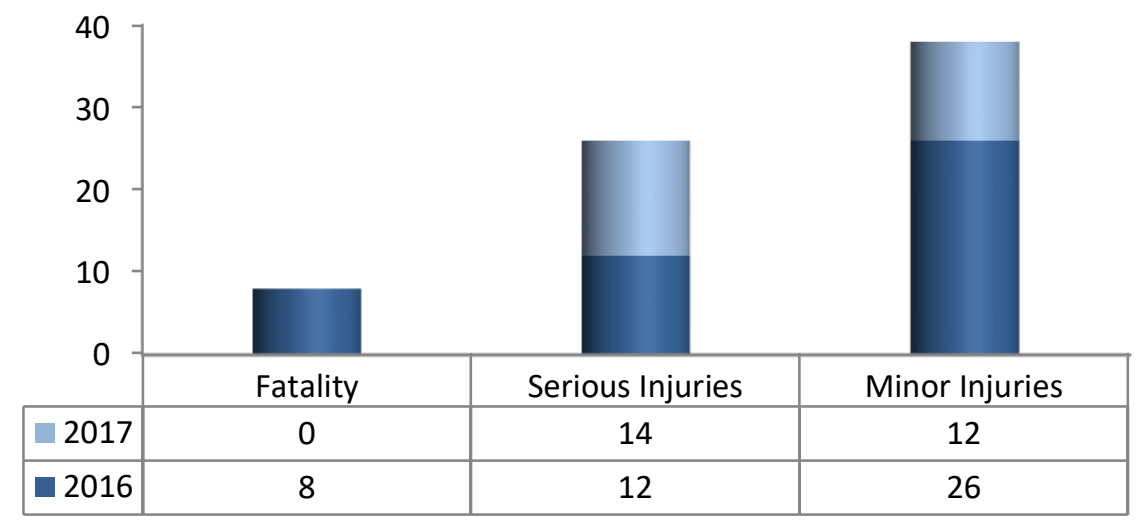

Gambar 2. Grafik Kecelakaan Kerja Tahun 2016-2017

Berdasarkan gambar 2. menunjukkan grafik kecelakaan kerja tahun 2016-2017, bahwa setiap tahun terjadi kecelakaan kerja yang mengakibatkan pegawai meninggal, luka berat dan luka ringan. Pada tahun 2017 terdapat penurunan kecelakaan kerja dengan kondisi luka ringan dan meninggal, namun terdapat peningkatan korban terjadinya kecelakaan kerja dengan kondisi luka berat sebesar $14,3 \%$.

Keselamatan dan kesehatan kerja harus ditanamkan pada diri masing-masing individu pegawai, dengan adanya pelatihan dan pembinaan yang baik agar menyadari pentingnya keselamatan kerja bagi dirinya maupun untuk perusahaan. Apabila banyak terjadi kecelakaan, pegawai banyak yang menderita, absensi meningkat, produktifitas menurun, dan biaya pengobatan semakin besar. Sehingga akan menimbulkan kerugian bagi pegawai maupun perusahaan yang tersebut, karena pegawai cacat ataupun meninggal dunia.

\section{Tujuan Penulisan}

Berdasarkan latar belakang yang telah dikemukakan terhadap Analisis Pelaksanaan Program Keselamatan dan Kesehatan Kerja dalam upaya Meminimalkan Kecelakaan Kerja pada Pegawai PT. Kereta Api Indonesia (PERSERO), maka penulis mempunyai tujuan kajian sebagai berikut:

1. Mengetahui jenis-jenis kecelakaan kerja yang terjadi pada karyawan PT. Kereta Api Indonesia (Persero).

2. Mengetahui pelaksanaan keselamatan dan kesehatan kerja karyawan PT. Kereta Api Indonesia (Persero) Depo Lokomotif Daop 2 Bandung.
3. Mengetahui upaya-upaya apa saja yang dilakukan untuk meminimalkan kecelakaan kerja PT. Kereta Api Indonesia (Persero).

\section{Kajian Teoritis}

\section{Manajemen Sumber Daya Manusia}

Manajemen berasal dari kata to manage yang artinya mengatur. Manajemen secara umum sering disebut sebagai suatu proses untuk menyelesaikan pekerjaan melalui orang lain. Definisi ini mengandung pengertian bahwa manajemen merupakan suatu ilmu dan seni yang mempelajari bagaimana cara mencapai tujuantujuan organisasi. Hal ini sejalan dengan apa yang diungkapkan oleh Malayu S.P. Hasibuan (2012;1), "Manajemen adalah ilmu dan seni mengatur proses pemanfaatan sumber daya manusia dan sumbersumber lainnya secara efektif dan efisien untuk mencapai suatu tujuan tertentu".

Manajemen sumber daya manusia dapat didefinisikan pula sebagai suatu pengelolaan dan pendayagunaansumber daya yang ada pada individu (pegawai). Pengelolaan dan pendayagunaan tersebut dikembangkan secara maksimal di dalam dunia kerja untuk mencapai tujuan organisasi dan pengembangan individu pegawai. Hal ini sejalan dengan apa yang diungkapkan oleh Malayu S.P. Hasibuan (2012:10), "Manajemen sumber daya manusia adalah ilmu dan seni mengatur hubungan dan peranan tenaga kerja agar efektif dan efisien membantu terwujudnya tujuan perusahaan, karyawan, dan masyarakat". (2013:2),
Menurut A. A. Anwar Prabu Mangkunegara 
"Manajemen sumber daya manusia merupakan suatu perencanaan, pengorganisasian, pengkoordinasian, pelaksanaan, dan pengawasan terhadap pengadaan, pengembangan, pemberian balas jasa, pengintegrasian, dan pemisahan tenaga kerja dalam rangka mencapai tujuan organisasi”.

Berdasarkan definisi tersebut maka dapat disimpulkan bahwa manajemen sumber daya manusia merupakan faktor penting dalam kegiatan organisasi atau perusahaan yang berperan dalam merencanakan, mengorganisasikan, mengarahkan, serta mengendalikan jalannya suatu kegiatan organisasi agar kegiatan organisasi dapat berjalan sesuai dengan tujuan organisasi.

Sedangkan menurut Marwansyah (2014:8) fungsi manajemen sumber daya manusia operasional yaitu :

\section{Perencanaan sumber daya manusia}

Perencanaan SDM adalah proses yang secara sistematis mengkaji kebutuhan SDM untuk menjamin terjadinya tenaga kerja dalam jumlah dan mutu, atau kompensasi, yang sesui pada saat dibutuhkan.

\section{Rekrutmen dan seleksi}

Rekrutmen adalah proses menarik sejumlah calon karyawan potensial dan mendorong mereka agar melamar pekerjaan pada sebuah organisasi. Seleksi adalah proses identifikasi orang-orang dari sekumpulan pelamar yang paling cocok dengan posisi yang ditawarkan dan dengan organisasi.

\section{Pengembangan SDM}

Pengembangan SDM adalah upaya terencana yang dilakukan oleh manajemen untuk meningkatkan kompensasi pekerja dan kinerja organisasi melalui program-program pelatihan, pendidikan, dan pengembangan.

\section{Kompensai}

Kompensasi atau balas jasa didefinisikan sebagi semua imbalan yang diterima oleh seseorang sebagai balasan atas kontribusinya terhadap organisasi

\section{Hubungan industrial}

Hubungan industrial atau hubungan pekerja adalah sebuah sitem hubungan yang terbentuk antara para pelaku dalam proses produksi barang dan/jasa yang terdiri atas unsur pengusaha, pekerja/buruh, dan pemerintah.

6. Penelitian sumber daya manusia
Penelitian atau riset sumber daya manusia adalah studi sistematis tentang sumber daya manusia sebuah perusahaan dengan maksud memaksimalkan pencapaian tujuan individu dan tujuan organisasi.

\section{Keselamatan dan Kesehatan Kerja}

Menurut

Wirawan

(2015:543) mengemukakan bahwa "Keselamatan kerja adalah kondisi dimana para pekerja selamat, tidak mengalami kecelakaan dalam melaksanakan tugas dan pekerjaannya. Sedangkan menurut Anwar Prabu Mangkunegara (2009: 161), mengemukakan bahwa: "Keselamatan kerja menunjukkan pada kondisi yang aman atau selamat dari penderitaan, kerusakan atau kerugian di tempat kerja”.

Menurut Malthis dan Jackson (dalam jurnal Rizkya dan Kusdi Raharjo; 2002), keselamatan kerja menunjuk pada perlindungan kesejahteraan fisik dengan dengan tujuan mencegah terjadinya kecelakaan atau cedera terkait dengan pekerjaan.

Tenaga kerja merupakan sumber daya yang memiliki peran yang sangat penting dalam berjalannya suatu perusahaan. Kesehatan tenaga kerja sangat penting untuk di perhatikan karena berpengaruh dengan produktivitas perusahaan.

Sutrisno (2007:7) mengemukaakan bahwa "Keselamatan kerja adalah sebagian ilmu pengetahuan yang penerapannya sebagai unsurunsur penunjang seorang kayawan agar selamat saat sedang bekerja dan setelah mengerjakan pekerjaannya"

Menurut Wirawan

mengemukakan bahwa kesehatan kerja adalah penerapan ilmu kesehatan atau kedokteran di bidang ketenagakerjaan yang bertujuan untuk mencegah penyakit yang timbul akibat kerja dan mempertahankan dan meningkatkan kesehatan para pekerja/buruh untuk meningkatkan kinerja mereka. Hartatik (2014:315) mengemukakan bahwa "kesehatan kerja merupakan suatu kondisi kesehatan yang bertujuan agar pekerja memperoleh derajat kesehatan setinggi-tingginya, baik jasmani, rohani, maupun sosial, dengan usaha pencegahan dan pengobatan terhadap penyakit atau gangguan kesehatan yang disebabkan oleh pekerjaan dan lingkungan kerja maupun penyakit umum”.

Sedangkan menurut Prabu Mangkunegara (2001) pengertian kesehatan kerja adalah kondisi bebas dari gangguan fisik, mental, emosi atau rasa sakit yang disebakan lingkungan kerja. Kesehatan dalam ruang lingkup keselamatan dan kesehatan kerja tidak hanya diartikan sebagai suatu keadaan bebas dari penyakit. 


\section{Kecelakaan Kerja dan Penyakit Akibat Kerja}

Dalam suatu proses produksi disebuah perusahaan yang menggunakan suatu alat maupun teknologi memiliki kecenderungan menimbulkan kecelakaan kerja bagi penggunanya. Maka penerapan program kesehatan dan keselamatan kerja perlu di perhatikan sebagai upaya mencegah terjadinya kecelakaan kerja.

Penerapan program K3 bukan sepenuhnya menjadi tugas perusahaan, namun program ini merupakan tugas semua pihak yang berhubungan dengan perusahaan. Semua pihak yang terkait harus melaksanakan program K3 secara optimal agar kecelakaan kerja di perusahaan dapat dihindari.

Menurut Undang-undang Nomor 40 Tahun 2004 tentang Jaminan Sosial Tenaga Kerja, "Kecelakaan kerja adalah kecelakaan yang terjadi dalam hubungan kerja, termasuk kecelakaan yang terjadi dalam perjalanan dari rumah menuju tempat kerja atau sebaliknya, dan penyakit yang disebabkan oleh lingkungan kerja".

Menurut Suma'mur (2009: 83) menyatakan bahwa penyebab penyakit akibat kerja disebabkan oleh faktor berikut, antara lain:

1) Faktor fisis seperti suara, radiasi sinar rongten atau sinar radio aktif, suhu yang terlalu tinggi, tekanan udara tinggi, dan penerangan lampu yang buruk.

2) Faktor kimiawi seperti debu, uap, gas, larutan kimia dan awan atau kabut.

3) Faktor biologis seperti bibit penyakit antraks atau brusella (brucella).

4) Faktor fisiologis/ ergonomis antara lain kesalahan konstruksi mesin, sikap badan tidak benar dalam melakukan pekerjaan.

5) Faktor mental-psikologis yang terlihat misalnya pada hubungan kerja atau hubungan industrial yang tidak baik".

Dari uraian diatas maka dapat diambil kesimpulan bahwa kecelakaan kerja merupakan kecelakaan yang timbul karena kelalaian manusia pada saat bekerja maupun faktor lingkungan yang berhubungan dengan pekerjaannya.

\section{Kerangka Pemikiran}

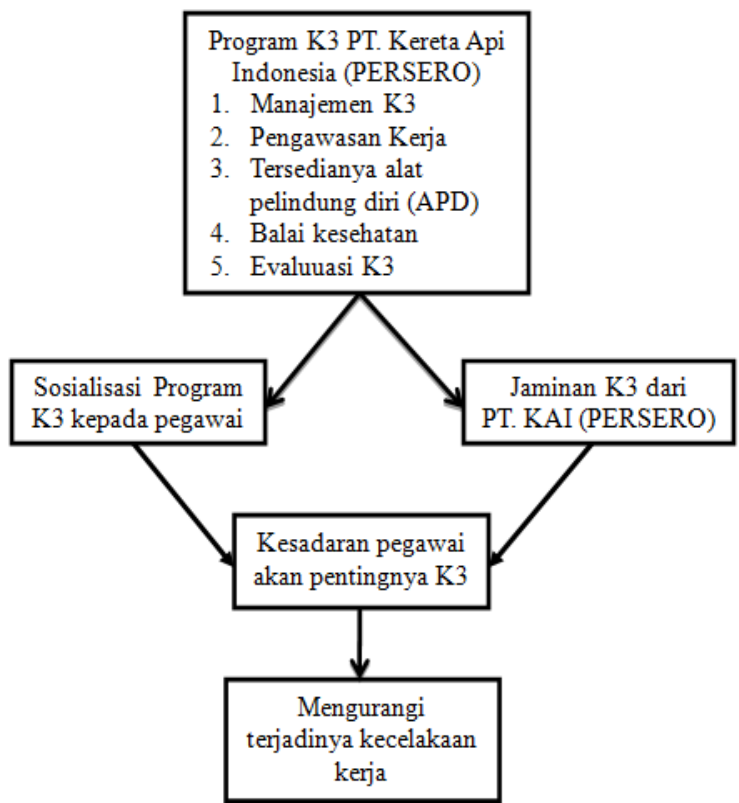

Gambar 3. Kerangka Pemikiran

\section{METODE PENELITIAN}

Penelitian ini merupakan penelitian deskriptif kualitatif. Penelitian deskriptif ini merupakan metode penelitian yang hanya menggambarkan keadaan berdasarkan fakta-fakta yang ditemukan dengan tidak menguji hipotesa maupun membuat prediksi.

Peneliti bermaksud menyajikan data secara sistematis, faktual dan akurat sesuai dengan kenyataan yang ada di dalam pelaksanaan program kesehatan dan keselamatan kerja pada Depo Lokomotif DAOP 2 Bandung PT. Kereta Api Indonesia (PERSERO).

Teknik pengumpulan data yang digunakan dalam penelitian ini antara lain: 1) Obserbvasi atau studi lapangan dengan pengamatan langsung, 2) Wawancara langsung dengan pihak terkait, dan 3) Dokumentasi.

Teknis analisis data yang digunakan dalam penelitian ini adalah analisis interaktif. Menurut Miles dan Huberman terdiri dari 3 alur kegiatan yang terjadi secara bersamaan, antara lain: 1)Reduksi data sebagai proses pemilihan, menggolongkan, dan penyederhanaan informasi dilapangan, 2) Penyajian data yang telah diperoleh, dan 3) Penarikan kesimpulan.

Secara skematis proses analisis data menggunakan model analisis data interaktif Miles dan Huberman dapat dilihat pada bagan berikut: 


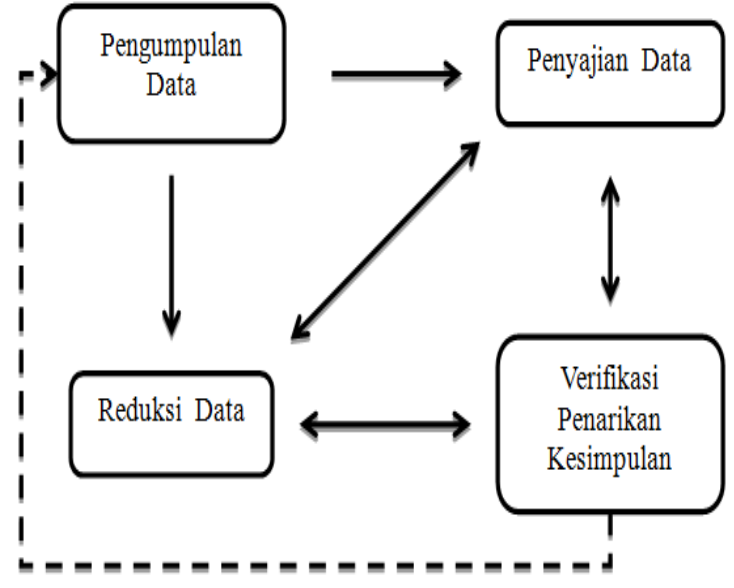

Gambar 4. Analisis Interaktif Miles dan Huberman

\section{HASIL DAN PEMBAHASAN}

\section{Jenis-Jenis Kecelakaan Kerja Yang Terjadi di PT. Kereta Api Indonesia}

Depo Lokomotif Bandung bertugas melakukan pemeriksaan terhadap 29 lokomotif yang beroperasi di Daerah Operasi 2 Bandung. Pemeriksaan dilakukan pada ruang diesel, rangka bawah dan setiap bagian dari lokomotif. Karyawan bekerja menggunakan berbagai alat mekanik dan elektrik Dilingkungan kerja Depo Lokomotif terdapat oli dan bahan bakar yang berceceran dilantai sehingga berpotensi mengakibatkan kecelakaan kerja bagi para pekerja dan orang lain yang terlibat di dalamnya.

Kecelakaan kerja dapat dibagi menjadi tiga jenis kecelakaan kerja, yaitu kecelakaan kerja ringan, kecelakaan kerja sedang dan kecelakaan kerja berat.

Kecelakaan kerja ringan merupakan kecelakaan kerja yang perlu pengobatan pada hari itu dan bisa melakakukan pekerjaannya kembali atau istirahat kurang dari 2 hari. Contoh kecelakaan kerja ringan diantaranya terpeleset, tergores, terkena pecahan beling, terjatuh dan terkilir.

Kecelakaan kerja sedang merupakan kecelakaan kerja yang memerlukan pengobatan dan perlu istirahat selama lebih dari 2 hari. Contoh kecelakaan kerja sedang diantaranya, terjepit, luka sampai robek, luka bakar.

Kecelakaan kerja berat merupakan kecelakaan kerja yang mengalami amputasi dan kegagalan fungsi tubuh. Contoh kecelakaan kerja berat yaitu patah tulang.

Kecelakaan kerja merupakan kejadian yang tidak diinginkan yang dapat menimbulkan kerugian baik bagi manusia maupun terhadap harta benda. Peneliti mewawancarai Bapak KI sebagai
KR Administrasi Depo Lokomotif Bandung, beliau menerangkan:

"Setiap karyawan sudah memahami keselamatan dan kesehatan kerja namun tidak dapat dipungkiri bahwa rekan-rekan bekerja berhadapan langsung dengan mesin diesel. Sehingga dapat terjadi kecelakaan kecil seperti tergores atau luka bakar kecil. Tetapi alhamdulillah sampai saat ini tidak ada kecelakaan kerja berat yang terjadi."

Berdasarkan hasil wawancara diatas dan observasi yang telah dilakukan, maka peneliti dapat menyimpulkan bahwa kecelakaan kerja yang terjadi pada karyawan bagian Daily Check Depo Lokomotif Bandung. Termasuk dalam kecelakaan kerja ringan hingga sedang.

\section{Pelaksanaan Program Keselamatan dan Kesehatan Kerja PT. Kereta Api Indonesia}

Program Keselamatan dan Kesehatan Kerja (K3) adalah suatu sistem yang dirancang untuk menjamin keselamatan yang baik pada semua personel di tempat kerja agar tidak menderita luka maupun menyebabkan penyakit di tempat kerja dengan mematuhi/taat pada hukum dan aturan keselamatan dan kesehatan kerja, yang tercermin pada perubahan sikap menuju keselamatan di tempat kerja.

\section{Penyediaan Alat Pelindung Diri}

Dalam upaya mendukung penerapan program Kesehatan dan Keselamatan Kerja di bagian Daily check Depo Lokomotif Bandung, PT. Kereta Api Indonesia (Persero) berkomitmen untuk memberikan fasilitas maupun sarana yang mendukung program tersebut. Ketika ditanyakan mengenai fasilitas maupun sarana yang diberikan kepada seluruh pegawai, Bapak KI menjelaskan antara lain:

\section{Alat pelindung diri}

Helm diberikan kepada setiap karyawan sebanyak satu buah dan wajib digunakan selama berada dilingkungan pekerjaan. Helm tersebut diberikan setiap satu tahun sekali. Perusahaan juga menyediakan helm bagi pengunjung yang memasuki area pekerjaan. Terdapat tiga warna helm yang digunakan untuk membedakan pekerja perusahaan, direksi perusahaan, dan pengunjung.

Kacamata pelindung diberikan kepada setiap karyawan sebanyak satu buah yang wajib digunakan selama proses pengecekan lokomotif.

Setiap karyawan mendapatkan 2 pelindung telinga yaitu earmuff dan earplug. Pelindung telinga tersebut digunakan selama proses pengecekan lokomotif, karena lokomotif mengeluarkan suara 
bising yang dapat mengganggu pendengaran. Pelindung telinga digunakan selama proses pengecekan lokomotif, karena suara bising yang dihasilkan oleh mesin diesel lokomotif tersebut.

Diberikan kepada setiap karyawan sebanyak satu buah rompi yang digunakan pada saat malam hari karena dapat memantulkan cahaya. Rompi wajib digunakan pada saat pengecekan rangka bawah lokomotif karena kurangnya pencahayaan.

Perusahaan memberikan beberapa masker kepada setiap karyawan yang diberikan setiap periodenya. Perusahaan juga menyediakan cadangan masker yang disimpan dan dikelola oleh bagian gudang.

Perusahaan memberikan sepatu safety berstandar nasional kepada setiap karyawan yang diberikan setiap tahun satu kali oleh perusahaan. Setiap orang yang memasuki wilayah kerja depo lokomotif wajib menggunakan sepatu keselamatan termasuk pengunjung.

Perusahaan memberikan beberapa sarung tangan kepada setiap karyawan setiap karyawan. Perusahaan juga menyediakan cadangan sarung tangan yang disimpan dan dikelola oleh bagian gudang.

Pelindung wajah disediakan oleh perusahaan disimpan dan dikelola oleh bagian gudang. Pelindung wajah digunakan pada saat melakukan kegiatan yang berhubungan dengan las listrik.

Setiap karyawan bagian mekanik mendapatkan baju pelindung yang wajib digunakan pada saat proses pengecekan lokomotif.

\section{Pengelolaan Sarana Keselamatan dan Kesehatan Kerja}

Sarana keselamatan dan kesehatan kerja merupakan fasilitas yang harus tersedia di lokasi tempat bekerja untuk menjamin kesehatan dan keselamatan pekerja. Adapun sarana keselamatan dan kesehatan kerja berdasarkan hasil observasi yang terdapat pada Depo Lokomotif Bandung yaitu, sebagai berikut:

Ruang Kerja yang disediakan perusahaan terdiri dari dua jalur untuk pengecekan rangka bawah, ruang diesel, elektrik maupun kabin lokomotif. Setiap karyawan mempunyai ruang loker yang menjadi tempat penyimpanan barang-barang pribadi.

Kantin berada disebrang ruang merokok, terpisah dengan bangunan Depo lokomotif dan berada di sudut area Unit Sarana Daop 2
Bandung.Kantin beroperasi setiap hari senin hingga sabtu, pada jam 08.00-16.00. Kantin hanya menyediakan makanan ringan dan berat yang sudah jadi karena terdapat larangan penggunaan api yang berasal dari kompor gas. Ketentuan tersebut bertujuan untuk menghindari terjadinya kebakaran. Kantin hanya diperbolehkan menggunakan pemanas air listrik untuk mengolah makanan.

Rest Area/Smooking Room yang disediakan perusahaan berada terpisah dari bangunan, sesuai dengan peraturan Menteri Kesehatan. Ruangan merokok berada diantara bangunan check lokomotif dan kantin berkonsep ruangan terbuka tanpa sekat ataupun dinding.

Kotak P3K hanya terdapat disudut dinding ruangan Kepala Ruas Administrasi yang berisi berbagai perban, hansaplas, cairan antiseptik, kain kassa, betadine, dan lain-lain.

Terdapat dua klinik kesehatan yang dapat melayani karyawan selama hari kerja senin sampai dengan sabtu dan hanya buka jam 08.00-14.00. Melayani kebutuhan karyawan yang membutuhkan dokter gigi dan dokter umum.

Pada saat memasuki pintu masuk gedung terdapat alat pemadam api yang berukuran cukup besar. Pemadam api tersebut berjenis carbon dioxida $\left(\mathrm{CO}_{2}\right)$ dengan menggunakan serbuk kimia (dry chemical) kering untuk memadamkan kayu, kertas, kain, plastik, listrik yang berkapasitas $20 \mathrm{~kg}$. Jenis ini bersifat bersih dan tidak meninggalkan residu sehingga cocok digunakan diarea mesin serta area yang banyak terdapat benda elektronik. Selanjutnya pada saat memasuki ruangan administrasi depo lokomotif terdapat alat pemadam api dengan kapasitas $5 \mathrm{~kg}$ yang cocok digunakan didalam ruangan, dengan disertai petunjuk penggunaan.

Sarana MCK dan Mushola berada didalam gedung Daily Check sehingga mudah untuk dijangkau oleh karyawan yang mau menunaikan ibadah.

\section{Sosialisasi Keselamatan dan Kesehatan Kerja}

Semua institusi berkewajiban untuk memastikan bahwa pekerja dan orang lain yang terlibat di lingkup operasionalnya untuk tetap berada dalam kondisi aman sepanjang waktu. Sepintas budaya keselamatan dan kesehatan kerja seolah hanya berlaku di lingkungan pekerjaan. Budaya merupakan selayaknya juga sudah menjadi suatu kebiasaan yang dapat terlaksana secara tepat dan baik apabila disosilisasikan secara maksimal.

Berdasarkan hasil observasi yang telah dilakukan, bahwa terdapat berbagai tindakan 
sosialisasi yang dilakukan oleh PT. Kereta Api Indonesia (Persero) diantaranya, sebagai berikut.

Pada saat memasuki area Sarana Daop 2 Bandung terdapat rambu "Area Terbatas dan Berbahaya" yang salah satunya terdapat anjuran penggunaan alat pelindung diri standar yang wajib digunakan. Pada saat memasuki gedung Depo Lokomotif Bandung terdapat berbagai spanduk dengan slogan "Safety is My Best Friends" dan "Semakin banyak identifikasi hazard merupakan prestasi unit mengenali dengan rinci tempat kerjanya." Semakin banyak safety action, semakin tinggi tingkat keselamatan diunitnya. Selanjutnya spanduk dengan slogan "Menjadikan Sistem Keselamatan Bagian Budaya Kerja Kita".

\section{Pelatihan dan Pendidikan K3}

Pelatihan Keselamatan Kesehatan Kerja dewasa ini semakin fundamental atau memiliki peranan penting baik tingkat nasional maupun secara global dunia. Pelatihan k3 banyak mempunyai manfaat penting khususnya dalam mengurangi kecelakaan dan penyakit didunia kerja. Dan Pengetahuan mengenai pelatihan K3 ini seharusnya diketahui oleh seluruh karyawan, bukan hanya bagi karyawan K3 saja.

Dengan semakin dipahami dan diketahui, maka output dari pelatihan K3 itu semua tentu saja untuk meningkatkan kemanan bekerja, profit dan image positif bagi perusahaan. Peneliti mewawancarai Bapak KI sebagai KR Administrasi Depo Lokomotif Bandung, beliau menerangkan:

"Ada sosialisasi kebakaran dilakukan satu atau dua tahun sekali dari pemadam kebakaran. Perwakilan dari depo sebanyak dua atau tiga karyawan yang akan dilatih di Daop mengenai potensi kebakaran dan cara penanganannya. ...seminar sosialisasi K3L yang dilakukan dengan mengirimkan perwakilan lalu disampaikan kepada rekan-rekan kerja lain yang tidak mengikuti melalu apel pagi ataupun meeting. Selanjutnya pusat akan mengadakan sidak kelapangan untuk mengevaluasi hasil sosialisasi yang telah dilakukan sebelumnya."

Berdasarkan wawancara tersebut, maka dapat disimpulkan sementara bahwa terdapat pelatihan dan pendidikan K3. Namun dalam pelaksanaanya masih kurang baik karena peserta perwakilan hanya berjumlah tiga orang dari keseluruhan pegawai Depo Lokomotif Bandung.

\section{Jaminan Pemeliharaan Kesehatan (JPK)}

JPK merupakan salah satu asuransi kesehatan khusus untuk pegawai Kereta Api yang bekerjasama dengan beberapa rumah sakit di daerah masing-masing. Untuk mengurus asurasnsi ini pegawai harus menunjukkan Kartu Bukti Diri (KBD) atau Kartu Multi Fungsi (KMF).

\section{Program Asuransi Kesehatan}

Asuransi kesehatan adalah sebuah jenis produk asuransi yang secara khusus menjamin biaya kesehatan atau perawatan para anggota asuransi tersebut jika mereka jatuh sakit atau mengalami kecelakaan. Secara garis besar ada dua jenis perawatan yang ditawarkan perusahaanperusahaan asuransi, yaitu rawat inap (in-patient treatment) dan rawat jalan (out-patient treatment).

BPJS merupakan singkatan dari Badan Penyelenggara Jaminan Sosial Kesehatan yaitu Badan Usaha Milik Negara (sebelumnya PT. ASKES) yang ditugaskan khusus oleh pemerintah untuk menyelenggarakan jaminan pemeliharaan kesehatan bagi seluruh rakyat Indonesia.

\section{Jaminan Kecelakaan Kerja}

Jaminan kecelakaan kerja memberikan perlindungan atas risiko-risiko kecelakaaan yang terjadi dalam hubungan kerja, termasuk kecelakaan yang terjadi dalam perjalanan dari rumah menuju tempat. Perlindungan atas risiko Kecelakaan Kerja mulai dari perjalanan pergi, pulang, dan ditempat bekerja, serta perjalanan dinas. PT. Kereta Api Indonesia (Persero) bekerja sama dengan BPJS Ketenagakerjaan untuk menyediakan jaminan terhadap kecelakaan kerja.

\section{Medical Check Up (MUC)}

Medical check up adalah pemeriksaan kesehatan secara menyeluruh. Melalui pemeriksaan ini diharapkan suatu penyakit atau gangguan kesehatan bisa dideteksi sejak dini. Tes ini sekaligus berguna untuk merencanakan metode penanganan dan pengobatan yang tepat sebelum penyakit berkembang.

Saat medical check up, pegawai akan menjalani sejumlah tahapan pemeriksaan menyeluruh, berupa konsultasi mengenai keluhan yang sedang dirasakan, pencatatan dan pemeriksaan berkaitan dengan riwayat kesehatan, pemeriksaan tanda vital tubuh dan kondisi fisik secara umum.

PT. Kereta Api Indonesia (Persero) bekerjasama dengan laboratorium klinik Biotest. Perusahaan mewajibkan pegawai untuk melakukan pemeriksaan kesehatan secara menyeluruh setiap tahunnya. Pemeriksaan tersebut meliputi pemeriksaan darah dan ronsen paru-paru.

\section{Kebijakan dan Disiplin Keselamatan Kerja}

Diperlukannya sikap disiplin agar kebijakan keselamatan dan kesehaan kerja dapat terlealisasi dengan baik. Peneliti mewawancarai Bapak KI 
sebagai KR Administrasi Depo Lokomotif Bandung, beliau menerangkan:

"Bagian SHE pusat akan mengadakan sidak kelapangan (Depo lokomotif) untuk mengadakan evaluasi hasil sosialisasi yang telah dilakukan sebelumnya. Sidak tersebut dilakukan secara mendadak tanpa ada pemberitahuan terlebih dahulu. Tidak ada tindakan disiplin yang diambil kecuali hanya teguran dari pimpinan".

Berdasarkan hasil wawancara tersebut, maka peneliti dapat menyimpulkan bahwa kurangnya kebijakan disiplin terkait keselamatan dan kesehatan kerja yang diberikan oleh pimpinan maupun bagian SHE pusat.

\section{Upaya Yang Harus Dilakukan Untuk Meminimalkan Kecelakaan Kerja Pada PT. Kereta Api Indonesia (Persero)}

PT. Kereta Api Indonesia (Persero) harus memperbaiki dan mengevaluasi kembali segala bentuk pelaksanaan program keselamatan dan kesehatan kerja. Melalui program keselamatan dan kesehatan kerja (Penyediaan Alat Pelindung Diri, Pengelolaan Sarana K3, Sosialisasi Keselamatan Dan Kesehatan Kerja, Pelatihan dan Pendidikan K3, Jaminan Pemeliharaan Kesehatan, Program Asuransi Kesehatan, Jaminan Kecelakaan Kerja, Medical Check Up) agar tentunya memotivasi lagi karyawan menjadi lebih aktif dan peduli terhadap keselamatan dan kesehatan kerja untuk meminimalkan kecelakaan kerja.

Ditinjau dari aspek kecelakaan kerja melalui observasi masih berada pada kategori ringan dan sedang, bisa ditingkatkan kembali oleh PT. Kereta Api Indonesia (Persero) dengan cara lebih aktif lagi dalam memberikan informasi atau membuat program-program baru untuk menarik minat karyawan.

\section{KESIMPULAN DAN SARAN}

\section{Kesimpulan}

Berdasarkan hasil penelitian yang diperoleh, maka dapat disimpulkan sebagai berikut:

1. Kecelakaan kerja yang terjadi pada karyawan bagian Daily Check Depo Lokomotif Bandung termasuk dalam kecelakaan kerja ringan hingga sedang.

2. Program keselamatan dan kesehatan kerja tidak dilakukan secara maksimal atau masih kurang baik karena kurangnya fasilitas dan sarana yang diberikan seperti, alat pelindung diri, ruang istirahat, dapur karyawan, dan jumlah peserta pelatihan $\mathrm{K} 3$.
3. PT. Kereta Api Indonesia (Persero) harus memperbaiki dan mengevaluasi kembali segala bentuk pelaksanaan program keselamatan dan kesehatan kerja. Melalui unsur keselamatan dan kesehatan (Penyediaan Alat Pelindung Diri, Pengelolaan Sarana K3, Sosialisasi Keselamatan Dan Kesehatan Kerja, Pelatihan dan Pendidikan K3, Jaminan Pemeliharaan Kesehatan, Program Asuransi Kesehatan, Jaminan Kecelakaan Kerja, Medical Check Up) agar tentunya memotivasi karyawan untuk lebih menjadi aktif serta peduli terhadap keselamatan dan kesehatan kerja dalam meminimalkan kecelakaan kerja.

\section{Saran}

Berdasarkan simpulan penelitian tersebut, maka dapat dikemukakan saran sebagai berikut:

1. Sebaiknya perusahaan menciptakan lingkungan kerja yang aman untuk pegawai agar kecelakaan kerja dapat semakin diminimalkan, sehingga produktivitas (perbandingan antara output hasil kerja dan input yang digunakan) tidak menurun karena terjadinya kecelakaan kerja.

2. Perusahaan sebaiknya memperbaiki sarana dan prasarana seperti ruang istirahat atau dapur untuk memenuhi kebutuhan makan dan minum karyawan. Jumlah alat pelindung diri masih belum sesuai dengan kebutuhan dan kenyamanan karyawan, maka untuk meminimalkan terjadinya kecelakaan kerja pada Depo Lokomotif Bandung, PT. Kereta Api Indonesia (Persero) bisa meninjau kembali kebijakan waktu pemberian dan jumlah alat pelindung diri yang disediakan. Bisa dengan menambah kotak P3K, waktu pemberian alat pelindung diri dipercepat dan jumlah yang diperbanyak.

3. Perusahaan sebaiknya memperbaiki program keselamatan dan kesehatan kerja agar tercapainya zero accident, melalui kerjasama dengan berbagai pihak diantaranya para ahli dan pemerintah.

\section{DAFTAR PUSTAKA}

Haerani, Rizkya dan Kusdi Raharjo. (2014). Pengaruh Keselamatan Dan Kesehatan Kerja Terhadap Kinerja Karyawan. Jurnal Administrasi Bisnis Vol.15 No.1 Oktober 2014. 
Hartatik, Indah P. (2014). Buku Praktis Mengembangkan SDM. Yogyakarta: Laksana.

Hasibuan. (2012). Manajemen Sumber Daya Manusia. Jakarta: Bumi Aksara.

Mangkunegara. (2013). Manajemen Sumber Daya Manusia Perusahaan. Bandung: Remaja Rosdakarya.

Marwansyah. (2014). Manajemen Sumber Daya Manusia, Edisi Kedua. Bandung: Alfabeta.

Republik Indonesia. (1970). Undang-Undang Nomor 1 Tahun 1970 tentang Keselamatan Kerja.

Republik Indonesia. (2004). Undang-Uundang Nomor 40 Tahun 2004 tentang Jaminan Sosial Tenaga Kerja.

Suma'mur. (2009). Keselamatan Kerja \& Pencegahan Kecelakaan. Jakata: Gunung Agung.

Sutrisno, Edi. (2009). Manajemen Sumber Daya Manusia. Jakarta: Kencana Prenada Media Group.

Wirawan. 2015. Manajemen Sumber Daya Manusia Indonesia. Jakarta: PT Raja Grafindo Persada. 